\title{
University Students' Acceptance of Online Learning During the Pandemic in Indonesia
}

\author{
Siti Yulidhar Harunasari ${ }^{1}$, Retno Dwigustini ${ }^{\text {, }}$, Nurhasanah Halim ${ }^{3}$, Susilawati 4
}

DOI: $10.35445 /$ alishlah.v13i1. 491

\begin{tabular}{l}
\hline Article Info \\
\hline Keywords: \\
Online learning \\
Students'Acceptance \\
Students'engagement \\
Covid 19
\end{tabular}

Kata kunci:

Pembelajaran daring

Penerimaan siswa

Keterlibatan siswa

Covid 19

\begin{abstract}
This research aimed to investigate students' acceptance of online learning during the pandemic by describing factors that sustain their engagement. The importance of this research is that by portraying their engagement in online learning, there would be suggestions for selecting effective strategies. A descriptive method was taken as the research method. A closed-ended equestionnaire distributed to 263 respondents was employed in collecting data and resulted in $75 \%$ response rates. The study concluded that more than $50 \%$ of students accepted that online learning was useful, but the technology was not easy to use. Their acceptance of online learning has influenced their engagement in the online learning environment and making them quite resourceful in responding to the practice of online learning during the pandemic. The most engaging factor in sustaining students' engagement was peer collaboration. Therefore, teamwork, peer-teaching, and peer assessment were among the main activities to sustain online learning engagement. Also, the communities of practice (CoP) could be lecturers' first choice to sustain students' engagement in online learning to anticipate the loss of authenticity in the learning context and trade the inexistence of concrete class, supporting facilities, and peers. The CoP could also make the learning context authentic. By implementing the two strategies, effective constructivist online learning should be achieved.
\end{abstract}

\begin{abstract}
Abstrak
Penelitian ini bertujuan untuk menyelidiki penerimaan siswa terhadap pembelajaran daring selama pandemi dengan mendeskripsikan faktor-faktor yang menopang keterlibatan mereka. Pentingnya penelitian ini adalah dengan menggambarkan keterlibatan mereka dalam pembelajaran daring akan ada saran dalam pemilihan kegiatan yang efektif. Metode deskriptif digunakan dalam penelitian ini. Penelitian ini menyimpulkan bahwa, di Indonesia, lebih dari 50\% siswa menerima bahwa pembelajaran daring bermanfaat tetapi tidak mudah dalam penggunaan teknologinya. Penerimaan ini mempengaruhi keterlibatan mereka dalam pembelajaran daring dan membuat mereka menjadi penuh gagasan dalam merespon praktiknya selama pandemi. Faktor yang sangat mempertahankan keterlibatan siswa adalah kolaborasi sesama. Oleh karenanya, bekerja dalam tim, pengajaran dan penilaian sejawat merupakan
\end{abstract}

${ }^{1}$ STKIP Kusumanegara, Jakarta, Indonesia

Email: yulidhar1@stkipkusumanegara.ac.id

2 Universitas Bina Sarana Informatika, Jakarta, Indonesia

Email: retno.rgu@bsi.ac.id

3 STKIP Kusumanegara, Jakarta, Indonesia

Email: nurhasanah halim@stkipkusumanegara.ac.id

4 STKIP Kusumanegara, Jakarta, Indonesia

Email: susilawatitoro@stkipkusumanegara.ac.id 
kegiatan utama yang harus ada dalam pembelajaran daring untuk menjaga keterlibatan siswa. Komunitas praktik juga bisa menjadi pilihan pertama bagi dosen untuk mempertahankan keterlibatan mahasiswa dalam pembelajaran daring sebagai antisipasi terhadap hilangnya keotentikan dalam konteks pembelajaran dan untuk mengganti ketiadaan kelas konkrit, fasilitas yang mendukung, dan teman sebaya. Pilihan ini juga bisa menciptakan konteks pembelajaran yang otentik. Dengan menerapkan kedua strategi ini, pembelajaran daring konstruktivis yang efektif akan tercapai.

\section{INTRODUCTION}

The outbreak of COVID-19 has been transforming all aspects of life. It is mainly for education that has undergone a total transformation. The move from face-to-face class to online learning has also been exhausting to lecturers and those responsible for supporting teaching instructions in higher education. However, the matter is no longer the delivery and the inversion of the class setting or even redesigning course content. Recent research reported that online learning effectiveness depends on the degree of acceptance of the user (Aguilera \& Hermida, 2020). Hence, investigating student's acceptance is now essential within the online learning context.

In principle, online learning is the extension of technology development which is the central aspect of students' experience in higher education. Overlooking online learning can put students' performance in isolation and put off their potentials. However, previous research on university students' engagement also reported that students actively participating in several numbers online courses are less exposed to effective teaching practices and experience a lower quality of interactions (Dumford \& Miller, 2018; Bond et al., 2020).

Although many have claimed that the so-called online learning during the pandemic is merely emergency remote teaching, it is commonly acknowledgeable as online learning. First used in 1995, online learning is a term that is employed to describe the first Learning Management System (LMS). This kind of online learning is limited to the use of LMS to upload texts and pdfs online. Distinctions and overlaps with electronic learning, blended learning, online education, online courses, mixedmode learning, and hybrid learning are frequent as ambiguity exists in each development of definitions and concept. Therefore, online learning and e-learning terms are interchangeable (Singh \& Thurman, 2019). The term online learning has developed in response to such associative elements as the learners' factors, the technology used, real-time learning, or even the percentages in its administration. Every element used to define the term can also be independent. Every definition will be in agreement with is the ultimate advantage that online learning offers: flexibility. It gives students control and opportunities to be flexible in where and when they learn. This flexibility covers student inability to attend the in-class meetings. Furthermore, the effectiveness of online learning will be accomplished when the prerequisite has been fulfilled, namely: information about the computer application, time management, organization, and online connection.

Despite the benefits offered, the drawbacks and challenges of online learning are never absent. Less engagement during students' collaboration, less conducive to student-lecturer interaction, and less effective teaching practices are drawbacks. Meanwhile, the challenges can lead to both students' and lecturers' frustration. From the students' perspectives, the posted resource materials were inadequate or insufficient to promote their understanding of the course content. On the contrary, lecturers argued that students are far from expectation. Most students showed less enthusiasm and get passive during online learning. In addition, keeping up-to-date with the latest technology was not an easy job. Students' disengagement is therefore detected. (Kassing, 2011; Ali, 2017; Dumford, \& Miller, 2018; Sarker, Mahmud, Islam, \& Islam, 2019).

However, to discuss students' engagement is more than considering it as the only critical predictor of a sustainable learning process. There are two associative elements to be considered: firstly, the amount of time and students' commitment to accomplish their learning goals and other instructional tasks and, secondly, the use of academic and non-academic tools to facilitate the 
involvement of students in activities relevant to their learning and development (Kuh et al., 2006). Unfortunately, in this concept of students' engagement in higher education, the socio-cultural context has not been largely attended (Kahu \& Nelson, 2018). Therefore, it has not reflected the environment in which the learning occurs (Lee et al., 2019).

Students' engagement in higher education is problematic as their engagement is theorized as a form of individuals' different function, which refers to how a group of individuals pronounce their aims and how to make sense of these aims (Kahn, 2014). The role of students relates to how they articulate their interests and how these goals make sense. Another point to consider is that students regard their tasks based on their emotional experiences towards the task assessment (Ketonen et al., 2019). Therefore, interventions should focus on the situations facilitating students' experience to promote positive feelings and reduce negative ones. The interventions could range from lecturers' helping students locate the value and meaning of their daily learning situations to lecturers' understanding of students' differences in approaches to study and learning style.

This descriptive research intends to investigate the students' acceptance of online learning during the pandemic by describing factors that sustain their engagement. Accepting or resisting online learning refers to students' perceptions toward usefulness and easiness influencing users' attitudes, intentions and actual behavior to use new technology (Ngampornchai \& Adams, 2016). However, either the acceptance or resistance can never be valid without students' engagement which is unarguable the only critical predictor of a sustainable learning process (Harunasari \& Halim, 2019).

Relevant studies on students' engagement were conducted by Lee et al. (2019) and Dumford, \& Miller (2018). Six factors to indicate students' engagement in the online learning environment were developed by Lee et al. (2019). They are psychological motivation (how students' think and feel about the online learning); peer collaboration (how students view their learning activities); cognitive problem solving (how students respond to the practice of learning, recognizing and utilizing information in an online learning environment); Interactions with Instructors (how lecturerstudents and student-student interaction can motivate learning and affect the process); community support (how the bond or sense of community was formed among students in the online courses), and learning management (how students manage their learning in the online learning). It is expected that the factors could support lecturers to improve student engagement in e-learning and the end, prevent students from dropping out of online courses. Dumford and Miller (2018) explored ways to take courses through an online medium that impacts student engagement. It was found that students who took greater online courses were more likely to engage in quantitative reasoning. They were less engaged in collaborative learning, student-faculty interactions, and discussions with peers than their engagement in concrete classes.

To sum, the importance of this research is that by portraying their engagement in online learning, there would be suggestions to the selection of effective online learning activities to sustain university students' engagement in Indonesia. Inappropriate learning context and students' resistance to online courses, which can cause a temporal and spatial disconnection between lecturers and learners, shall be minimized. Nowadays, online learning has been a challenge to every educational institution as there will not be any return to the pre-COVID situation (Schultz \& DeMers, 2020).

\section{METHODS}

\section{Research Method}

This was descriptive research. The goal is to solve problems and improve practices through observation, analysis, and description. An electronic questionnaire was employed to collect data. The data collection was administered online; web-based software was used to attain data efficiently (Denzin \& Lincoln, 2018). 


\section{Participants}

198 university students participated voluntarily in this research. The students were from two private universities in Jakarta. They were divided into three age groups: 18-20 years old, 21-23 years old and $>24$ years old. The student-respondents were from four different major programs. Their majors were Business Administration, English Language Education, Communication, and Management, with the most students from the Business Administration. To sum, female students in the first age group were more responsive to the e-questionnaire in this survey. Table 1 reported respondents' demographic data.

Table 1. Respondents' Demographic Data

\begin{tabular}{clc}
\hline & Demographic Data & Percent (\%) \\
\hline Age & & \\
& $18-2$ years old & 45.5 \\
& $21-23$ years old & 41 \\
Sex & $\geq 24$ years old & 13.5 \\
& Female & 77.3 \\
Study Programs & Male & 22.7 \\
& Business Administration & \\
& English Language Education & 29.3 \\
& Communication & 28.9 \\
& Management & 24.2 \\
\end{tabular}

\section{Research Procedures}

The data collection was from January to February 2021. It began with a sampling frame containing students' contact email addresses to direct students to the e-questionnaire https://bit.ly/2JcTiai. The use of e-questionnaire was to reach many students and avoid physical contact during the pandemic. This method is reliable in minimizing coverage error as the respondents were invited to participate in the survey. Hence, researchers need to compute the response rate as the number of potential respondents has been known in the first place. The response rate can be specified as the percentage of the sample respondent that has answered and returned the questionnaire. The pre-notification text message was also used to increase the response rates (Manzo \& Burke, 2012).

The student respondents were from two private universities in Jakarta and selected using saturation sampling. There were 263 students' email addresses collected, with 198 students answered and returned the e-questionnaire. This has brought a high response rate to the research 75\% (Paolo et al., 2000), and high validity of the result (Manzo \& Burke, 2012).

In the e-questionnaire, students responded to a 5-point scale of Likert commonly used to assess attitudes, personality factors, and other psychological conditions. The five points are Strongly agreed (5), Agree (4), Undecided (3), Disagree (2), Strongly Disagree (1). The use of midpoint in this questionnaire gives respondents considerable freedom to express both the direction and strength of their acceptance toward the new technology-enhanced online learning. This middle point can represent students' real attitudes in opinion measurement and reduce some response bias. A fivepoint Likert scale is also the best option to attain an information-processing perspective (Chen 2015; Cohen, Manion and Morrison, 2018).

A closed-ended questions survey was used to obtain data on students' sustainable online learning engagement following a pilot test. Six factors were proposed: Psychological Motivation; Peer Collaboration; Cognitive Problem Solving; Interactions with Instructors; Community Support, and Learning Management (Lee et al., 2019). During the survey, the questionnaire items have been 
adapted for the significance of the study. Each characteristic was represented by 2-5 measuring items in the form of positive statements.

The collected data was through three parallel activities taken from qualitative analysis: condensation, display, and verification (Miles et al., 2014). The condensation began by transforming the survey responses into percentages using the basic excel percentage formula (Part/Total = Percentage). Three categories only agree with the statements, undecided and disagreeing with the statements. Next, the researchers decided which data would be focused on by sorting them from the highest to the lowest percentage of each point. After that, the data were displayed and verified.

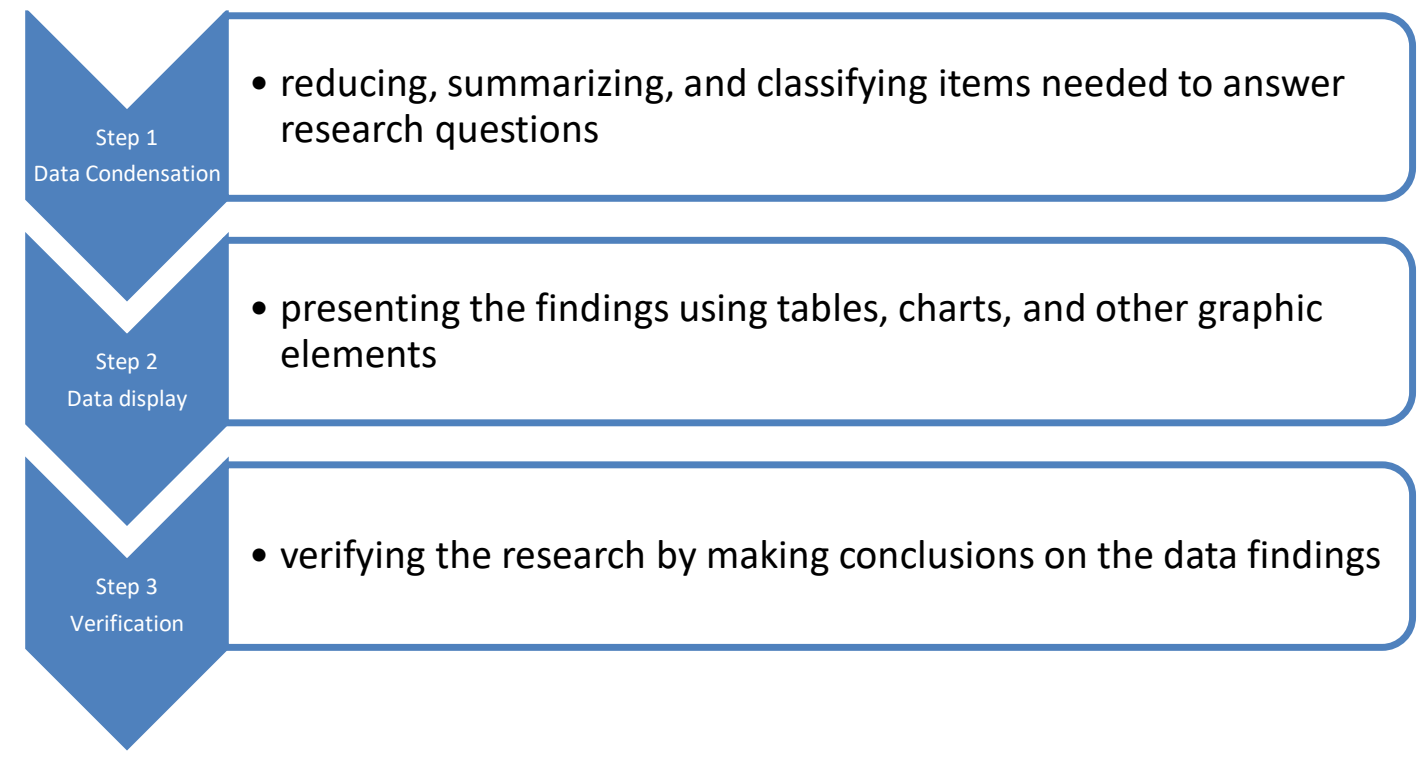

Figure 1. Steps in Data Analysis

\section{FINDINGS AND DISCUSSION}

After condensed, the data were displayed and verified. Subheadings are used to display the research findings of factors sustaining online learning engagement. Discussions of research findings were to verify the findings. Then, suggestions of effective online learning activities are made in conclusion.

\section{How Students' Feel and Think About the Online Learning}

The first engagement factor reflected students' thoughts or emotions, which was relevant to the online learning motivation. This factor could reflect students' interest, expectation, and motivation. Based on the survey, 50\% of participants felt so enthusiastic that they were expecting the following online classes. $43 \%$ of students were satisfied, and $41 \%$ of students perceived that online learning was useful during the pandemic. These could be seen from the three items with which most students agree the most. What unfortunate was that students have not thought that their online classes interesting and motivating their learning. This was represented by one-third of the total participants choosing the middle point in items 3 and 6. Referring to (Kuh et al., 2006), it was found that students' engagement stands at an intersection of students' reactions and the HE institutional conditions. Meanwhile, the acceptance of student for online learning was in between.

Tugun et al. (2020) stated that there were several possibilities why students were not fully interested and motivated in online learning. First, online learning during the pandemic was the only practical solution in teaching delivery. It is the ultimate response to adapt to the COVID-19 lockdown. The planning was insufficient since the goal was to deliver the course with time efficiency. Therefore, the students showed a negative response to online learning. Next, the lack of lecturers' technical expertise and the inadequate provision of sufficient technology support needs to be fulfilled to bring effective online learning. These should be the university management's top priorities in 
developing better online learning during this uncertain time. To sum, students felt enthusiastic and thought that their online learning was satisfying and valuable. Table 2 reported students' response to the factor.

\section{Table 2. Summary of Students' Psychological Motivation in the Online Learning}

\begin{tabular}{llccc}
\hline \multicolumn{1}{c}{ Psychological Motivation } & \multicolumn{3}{c}{ Response Percent } \\
\cline { 3 - 5 } & & Agreement & Undecided & Disagreement \\
\hline 1. $\begin{array}{l}\text { Even my session has just been completed, I } \\
\text { have been looking forward to the next }\end{array}$ & 50 & 30 & 20 \\
classes. & & & \\
2. I am satisfied with the online class I took. & 43 & 29 & 29 \\
3. I find that online classes are very useful. & 41 & 34 & 25 \\
4. For me, online classes are very interesting. & 39 & 32 & 29 \\
5. Online classes can enhance my interest in & 33 & 30 & 37 \\
learning. & 31 & 34 & 35 \\
6. Online classes motivate me to study. & & & \\
\hline
\end{tabular}

\section{How Students View Their Learning Activities}

The second factor in sustaining students' engagement in online learning was peer collaboration. This factor referred to events at which students could discuss information and address issues in collaboration. Table 3 reported that most students (82\%) viewed their peers as supportive when they could not grasp the theories, principles, concepts, etc., taught or learned in the online activities. This, of course, included their efforts to solve challenging issues in collaboration. Students mutually supported each other during the online learning. Students were not hesitant or reluctant to ask other students' help when they failed in meaning-making about the concept taught in their online classes. Many of the students collaborated with other students to complete their online tasks or assignments. To sum, students positively viewed their learning because of the collaborative peer learning.

The summary has been evidence of the success in online learning during the pandemic. This is in line with the finding of Rapanta, C., Botturi, L., Goodyear, P. et al. (2020) that a successful online course promotes peer collaboration. Disregarding the classroom setting (online class or concrete class), collaboration is crucial for students to gain skills (Cohen, 2003; Dumford and Miller, 2018). They tend to be more active in grasping theories, principles, concepts by interacting with their peers.

Table 3. Summary of Students' Psychological Motivation in the Online Learning

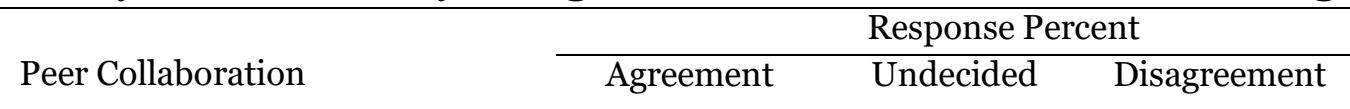

\begin{tabular}{|c|c|c|c|c|}
\hline 1. & $\begin{array}{l}\text { I get help from other students when I cannot } \\
\text { grasp a concept taught in my online class. }\end{array}$ & 82 & 12 & 7 \\
\hline & $\begin{array}{l}\text { I try to minimize difficult problems } \\
\text { encountered with other students }\end{array}$ & 81 & 12 & 9 \\
\hline 3 . & I study the lesson contents in collaboration. & 77 & 15 & 9 \\
\hline 4. & $\begin{array}{l}\text { I work on online projects or assignments in } \\
\text { collaboration }\end{array}$ & 75 & 13 & 12 \\
\hline 5 . & $\begin{array}{l}\text { I attempt to answer the questions asked by } \\
\text { other students. }\end{array}$ & 69 & 23 & 8 \\
\hline
\end{tabular}

\section{How Students Respond to the Practice of Learning, Recognizing, And Utilizing Information in Online Learning Environment}

The third factor in measuring students' engagement in online learning is cognitive problemsolving. This factor measures how students responded to learning, recognizing, and utilizing 
information in the online learning environment. The practice was in the forms of tasks or activities engaging students to think about important concepts, skills, and knowledge they need to master. Based on Table 4, it was reported that $60 \%$ of students have positively responded to the practice by being aware of adapting their approaches to learning with a new perspective. This awareness has led students to decide the relevance of knowledge acquired during the online classes and give opportunities for themselves to be resourceful by applying the knowledge to solve real problems in new situations. It implied that students were quite resourceful in responding to the practice of online learning during the pandemic. However, from the last items, it can be inferred that students are still unsure whether they can use the newly acquired in a larger related area. This doubt has become challenge for lecturers in online learning. The practice of online learning could disregard the authenticity of required learning conditions (Lee, 2018).

The report gives insights that students' decision to adapt to the new learning mode has quite influenced their engagement in the online learning environment. There should be a further investigation to determine what difficulties or barriers are encountered so that students need to adapt to the new mode of learning. Based on Baticulon et al. (2020), the difficulties would be adjusting learning styles, the performance of students' task, and the poor communication between the lecturer and the students. Similar to the aim of this recent study, it is not only the students adapting to a new mode of learning. Lecturers should provide different tasks to bridge the absence of lecturer-students interaction in online learning (König, Jäger-Biela \& Glutsch, 2020).

Table 4. Summary of Students' Cognitive Problem-Solving in the Online Learning

\begin{tabular}{|c|c|c|c|}
\hline \multirow[b]{2}{*}{ Cognitive Problem Solving } & \multicolumn{3}{|c|}{ Response Percent } \\
\hline & Agreement & Undecided & Disagreement \\
\hline $\begin{array}{l}\text { 1. I want to view the topic learned in the online } \\
\text { class from a particular perspective. }\end{array}$ & 60 & 30 & 10 \\
\hline $\begin{array}{l}\text { 2. I have always attempted to adapt materials } \\
\text { taught in online classes to real problems or } \\
\text { unfamiliar situations. }\end{array}$ & 59 & 31 & 11 \\
\hline $\begin{array}{l}\text { 3. I can assess the relevance of background } \\
\text { information to value the experience in my online } \\
\text { classes. }\end{array}$ & 59 & 29 & 13 \\
\hline $\begin{array}{l}\text { 4. I can create new interpretations and elaborate } \\
\text { ideas from the new information based on the new } \\
\text { things I've learned in my online courses. }\end{array}$ & 51 & 36 & 12 \\
\hline $\begin{array}{l}\text { 5. I can do in-depth analysis about thoughts, } \\
\text { experiences, and theories gained in my online } \\
\text { classes. }\end{array}$ & 47 & 34 & 19 \\
\hline
\end{tabular}

\section{How Lecturer-Students and Student-Student Interaction Can Motivate Learning and Affect the Process}

This factor was measured to demonstrate the behavioral participation of the learner in engaging with the teacher of the online course. Table 5 has summed students' responses to interaction with instructors in online learning. Based on this table, students agreed that modes of communication, either in private or during online learning, had supported students' need to grasp the meaning of content, information, etc. It also implied that students were active participants during online classes. Moreover, all the percentages exceeded 50\%. This also showed that students' level of engagement was high. From this character, it can be concluded that students accepted online learning during the pandemic. The environment had influenced students' motivation to engage with the learning process. This finding is in line with the study conducted by Lee (2018), who found that the strong, multichannel interaction between lecturer and learner in online learning is effective in 
the learners' cognitive development. Therefore, interaction within online learning has motivated students learning greatly affected the process.

Table 5. Summary of Students' Interaction with Instructors in the Online Learning

\begin{tabular}{llccc}
\hline \multicolumn{2}{c}{ Interactions with Instructors } & \multicolumn{2}{c}{ Response Percent } \\
\cline { 3 - 4 } & I can communicate with the lecturers in & 65 & Undecided & Disagreement \\
\hline $\begin{array}{l}\text { private for extra help. } \\
\text { I often ask lecturers about the contents of the } \\
\text { lesson. }\end{array}$ & 64 & 22 & 13 \\
\end{tabular}

\section{How the Bond or Sense of Community Was Formed Among Students in the Online Courses}

This factor was relevant to students' psychological condition. This referred to forming a bond or sense of community formed by learners who were learning in the same online courses. This factor summarizes that students were emotionally bound in the online learning community because of their frequent interaction with other students. The sense of belonging in the online class and feeling connected were aspects that sustained students' engagement. The finding implied that the learning context had been appropriate. Consequently, the time and space gaps between lecturers and learners did not exist. The gaps have been concerned for teachers also as it significantly affects the learning assessment (Dumford \& Miller, 2018; König, Jäger-Biela \& Glutsch, 2020). Table 6 reported students' responses toward community support in online learning.

Table 6. Summary of Community Support in the Online Learning

\begin{tabular}{llccc}
\hline \multicolumn{1}{c}{ Community Support } & \multicolumn{2}{c}{ Response Percent } \\
\cline { 3 - 5 } & Agreement & Undecided & Disagreement \\
\hline 1. $\begin{array}{l}\text { During online classes, I frequently interact with } \\
\text { other students. }\end{array}$ & 73 & 17 & 11 \\
2. $\begin{array}{l}\text { During the online class community, I feel the } \\
\text { sense of belonging established. }\end{array}$ & 69 & 20 & 12 \\
3. $\begin{array}{l}\text { During online classes, I feel connected with other } \\
\text { students. }\end{array}$ & 60 & 23 & 17 \\
\hline
\end{tabular}

\section{How Students Manage Their Learning in the Online Learning}

The last factor in sustaining students' engagement in online learning was learning management. This is relevant to active and self-directed learning experiences in students' learning environments. It can be inferred that students managed their learning schedules by planning them. Yet, distractions were unavoidable. Any distraction might have been one limitation in online learning.

Sarker, Mahmud, Islam, \& Islam (2019) found that the cause of constraints in online learning was lack of planning and organization in the course delivery. It is believed that the sudden shift from face-to-face class to online learning has contributed mainly to the constraints. Moreover, previous research by Henrie, Halverson, \& Graham (2015) found that students' experience in online learning could vary depending on the individuals. It can be inferred that distractions exist when tasks have failed students to manage their learning. Table 7 summed students' responses in the online learning management. 


\section{Table 7. Summary of Learning Management in the Online Learning}

\begin{tabular}{llccc}
\hline \multicolumn{1}{c}{ Learning Management } & \multicolumn{3}{c}{ Response Percent } \\
\cline { 2 - 4 } & Agreement & Undecided & Disagreement \\
\hline 1. & $\begin{array}{l}\text { I plan a learning schedule before the online } \\
\text { learning. }\end{array}$ & 72 & 20 & 8 \\
2. $\begin{array}{l}\text { I study relevant material by myself after the } \\
\text { online learning session. }\end{array}$ & 68 & 24 & 9 \\
3. I have my own systematic online learning & 67 & 26 & 10 \\
$\begin{array}{l}\text { management. } \\
\text { 4. I remove all environmental distractor factors } \\
\text { during online classes. }\end{array}$ & 62 & & 13 \\
\hline
\end{tabular}

\section{CONCLUSION}

The purpose of the current study was to investigate students acceptance of online learning. Like those in other countries affected by the COVID-19 lockout, Universities in Indonesia began the 2020 academic year with an "irregular" freshmen's welcoming ceremony held online. Platforms of video conferencing replaced freshmen's excitement to see their campuses and adapt to university students' lives. At some points, this adaptation has led to learning difficulties, stress, and anxiety, yet it has given the best opportunity for students to be resilient, resourceful, and independent.

The most significant finding to emerge from this study was that the factor which mostly sustains students' engagement in online learning during the pandemic is peer collaboration. When administered for several weeks, an online course encouraged peer collaboration. Technology provides various engagement patterns for students, encouraging small group discussion, promoting opinion exchange, peer review, and creating an online learning society. A point to consider is that the challenges of coordinating group work in an online-based learning environment can be addressed by proper preparation, setting specific learning guidelines, and selecting relevant content material and task types. It can be concluded that teamwork, peer-teaching, or peer assessment are compulsory in selecting course activities. The second major finding was that the communities of practice (CoP) could be lecturers' first choice to sustain students' engagement in online learning to anticipate the loss of authenticity in the learning context and trade the inexistence of concrete class facilities peers. The CoP could also make the learning context authentic. By implementing the two strategies, effective constructivist online learning should be achieved.

This study concluded that many students have perceived that the so-called disruptive technology in their learning during the pandemic as useful but not easy in Indonesia. This acceptance of online learning has influenced their attitude and behavior toward the use of technology. Students' decision to adapt to the new mode of learning has then influenced their engagement in the online learning environment. It makes them quite resourceful in responding to online learning during the pandemic. However, caution must be applied with a limited sample size, as the findings might not be transferable to a larger Indonesian context. Thus, it is recommended to conduct further research with large randomized controlled trials, providing more definitive evidence.

\section{REFERENCES}

Ali, S. (2017). E-learning implementation barriers: impact of student's individual cultural orientation on e-learning device acceptance (Doctoral dissertation, University of Reading).

Baticulon, R., Alberto, N.R., Baron, M., Mabulay, R.E., Rizada, L.G., Sy, J., Tiu, C., Clarion, C.A., \& Reyes, J.C. (2021). Barriers to online learning in the time of COVID-19: A national survey of medical students in the Philippines. Medical Science Educator. https://doi.org/10.1007/s40670-021-01231-z

Bond, M., Buntins, K., Bedenlier, S. et al. (2020). Mapping Research in Student Engagement and Educational Technology in Higher Education: A Systematic Evidence Map. Int J Educ Technol High Educ 17, 2 https://doi.org/10.1186/s41239-019-0176-8

Bryant, J., \& Bates, A. J. (2015). Creating a constructivist online instructional environment. 
TechTrends, 59(2), 17-22. https://doi.org/10.1007/s11528-015-0834-1.

Chen, X., Yu, H., \& Yu, F. (2015). What is The Optimal Number of Response Alternatives for Rating Scales? From an Information Processing Perspective. Journal of Marketing Analytics, 3, 6978.

Cohen, Louis., Lawrence Manion and Keith Morrison. (2018). Research Methods in Education: Eighth Edition. Routledge: New York.

Cohen, V.L. (2003). A Model for Assessing Distance Learning Instruction. Journal of Computing in Higher Education. 14, 98-120. https://doi.org/10.1007/BFo2940940

Denzin, N. K., \& Lincoln, Y. S. (Eds.). (2018). The SAGE handbook of qualitative research (5th ed.). SAGE Publications.

Dumford, Amber D., Angie L. Miller. (2018). Online Learning in Higher Education: Exploring Advantages and Disadvantages for Engagement, $J$ Comput High Educ. https://doi.org/10.1007/s12528-018-9179-Z

Harunasari, S. Y., \& Halim, N. (2019). Digital backchannel: Promoting students' engagement in EFL large class. International Journal of Emerging Technology in Learning, 14(7), 163-178. https://doi.org/10.3991/ijet.v14i07.9128.

Henrie, C. R., Halverson, L. R., \& Graham, C. R. (2015). Measuring Student Engagement in Technology-mediated Learning: A Review. Computers \& Education, 90, 36-53. https://doi.org/10.1016/j.compedu.2015.09.005.

König, Johannes., Daniela J. Jäger-Biela, \& Nina Glutsch. (2020). Adapting to Online Teaching during COVID-19 School Closure: Teacher Education and Teacher Competence Effects Among Early Career Teachers in Germany, European Journal of Teacher Education, 43:4, 608-622, https://doi.org/10.1080/02619768.2020.1809650

Kahn, P. E. (2014). Theorising student engagement in higher education. British Educational Research Journal, 4O(6), 1005-1018. https://doi.org/10.1002/berj.3121.

Kahu, E. R., \& Nelson, K. (2018). Student engagement in the educational interface: Understanding the mechanisms of student success. Higher Education Research \& Development, 37(1), 58-71. https://doi.org/10.1080/07294360.2017.1344197.

Ketonen, E. E., Malmberg, L. E., Salmela-Aro, K., Muukkonen, H., Tuominen, H., \& Lonka, K. (2019). The role of study engagement in university students' daily experiences: A multilevel test of moderation. Learning and Individual Differences, 69(October 2018), 196-205. https://doi.org/10.1016/j.lindif.2018.11.001.

Kuh, G. D., Kinzie, J., \& Buckley, J. A. (2006). What matters to student success : A review of the literature spearheading a dialog on student success. In Commissioned Report for the National Symposium on Postsecondary Student Success Spearheading a Dialog on Student Success (Vol. 18, Issue July). http://cpe.ky.gov/NR/rdonlyres/AFA304Fo-C125-40C2-96E57A8C98915797/o/WhatMatterstoStudentSuccessAReviewoftheLiterature.pdf.

Lee, J., Song, H., \& Hong, A. (2019). Exploring factors, and indicators for measuring students' $\begin{array}{llll}\text { sustainable engagement in e-learning. Sustainability, } & 11(4), \quad 985 .\end{array}$ https://doi.org/10.3390/su11040985.

Lee, K. (2018). Everyone already has their community beyond the screen: reconceptualizing online learning and expanding boundaries. Educational Technology Research and Development, 66(5), 1255-1268. https://doi.org/10.1007/s11423-018-9613-y.

Manzo, A. N., \& Burke, J. M. (2012). Increasing response rate in web-based/internet surveys. In Handbook of survey methodology for the social sciences (pp. 327-343). https://doi.org/10.1007/978-1-4614-3876-2 19.

Miles, M. B., Huberman, A. M., \& Saldana, J. (2014). Qualitative data analysis: A methods sourcebook. Sage Publications, Inc.

Ngampornchai, A., \& Adams, J. (2016). Students' acceptance and readiness for e-learning in Northeastern Thailand. International Journal of Educational Technology in Higher Education, 13(34), 1-13. https://doi.org/10.1186/s41239-016-0034-X.

Paolo, A. M., Bonaminio, G. A., Gibson, C., Partridge, T., \& Kallail, K. (2000). Response rate comparisons of e-mail- and mail-distributed student evaluations. Tech Learn Med, 12(2), 8184. https://doi.org/10.1207/S15328015TLM1202 4.

Patricia Aguilera-Hermida, College students' use and acceptance of emergency online learning due to COVID-19, International Journal of Educational Research Open, Volume 1, 2020, https://doi.org/10.1016/j.ijedro.2020.100011 
Rapanta, C., Botturi, L., Goodyear, P. et al. (2020). Online University Teaching During and After the Covid-19 Crisis: Refocusing Teacher Presence and Learning Activity. Postdigit Sci Educ 2, 923945.. https://doi.org/10.1007/s42438-020-00155-y

Sarker, M. F. H., Mahmud, R. A., Islam, M. S., \& Islam, M. K. (2019). Use of e-learning at higher educational institutions in Bangladesh. Journal of Applied Research in Higher Education. https://doi.org/10.1108/jarhe-06-2018-0099

Schultz, R. B., \& DeMers, M. N. (2020). Transitioning from emergency remote learning to deep online learning experiences in geography education. Journal of Geography, 119(5), 142-146. https://doi.org/10.1080/00221341.2020.1813791.

Singh, V., \& Thurman, A. (2019). How many ways can we define online learning? A systematic literature review of definitions of online learning (1988-2018). American Journal of Distance Education, $33(4)$, 289-306. https://doi.org/https://doi.org/10.1080/08923647.2019.1663082.

Tugun, V., Bayanova, A. R., Erdyneeva, K. G., Mashkin, N. A., Sakhipova, Z. M., \& Zasova, L. V. (2020). The opinions of technology supported education of university students. International Journal of Emerging Technologies in Learning, 15(23), 4-14. https://doi.org/10.3991/ijet.v15i23.18779. 